\title{
Associated factors with physical activity counseling among Brazilian Family Health Strategy workers
}

\author{
Fatores associados ao aconselhamento em atividade física entre \\ trabalhadores da Estratégia Brasileira de Saúde da Família
}

João Miguel de Souza Neto (https://orcid.org/0000-0001-6572-4884) ${ }^{1}$

Alex Antônio Florindo (https://orcid.org/0000-0002-4429-0826) ${ }^{2}$

Filipe Ferreira da Costa (https://orcid.org/0000-0003-3632-9310) ${ }^{3}$

${ }^{1}$ Programa Associado de Pós-Graduação em Educação Física, Universidade Federal da Paraíba (UFPB). Jardim Universitário $\mathrm{s} / \mathrm{n}$, Castelo Branco. 58051-900 João

Pessoa PB Brasil. miguel.edf@hotmail.com

${ }^{2}$ Escola de Artes, Ciências e Humanidades, Universidade de São Paulo. São Paulo SP Brasil.

${ }^{3}$ Departamento de

Educação Física, UFPB. João Pessoa PB Brasil.

\begin{abstract}
This study aimed to determine the prevalence and associated factors with physical activity counseling among Brazilian Family Health Strategy workers. This is a cross-sectional study conducted with a random sample of 591 health workers who work in the Family Health Teams of João Pessoa-PB, Brazil. Counseling for physical activity was defined as any advising targeted for increasing patients' physical activity levels conducted for at least six months. The following factors were considered: time working in health care units, amount of daily attendance, continuing education, perceived barriers, self-efficacy, attitude, self-rated health, physical activity level and nutritional status. Prevalence of counseling was $46.3 \%$, being higher among physicians (74.5\%; 95\%CI: 59.6-85.2) and nurses (60.3\%; 95\%CI: 48.0-71.4) compared to community health workers (42.9\%; 95\%CI: 38.2-47.7) and nurses assistants (31.5\%; 95\% CI: 20.2-45.4). The results showed health professionals with positive self-rated health, without perception of barriers, having a positive attitude and high self-efficacy were more likely to perform physical activity counseling. Knowledge and actions on factors associated with physical activity counseling can help broaden the involvement of primary health care providers in health education.
\end{abstract}

Key words Health personnel, Preventive counseling, Primary Health Care, Motor Activity
Resumo O estudo objetivou determinar a prevalência e os fatores associados ao aconselhamento para atividade física entre trabalhadores da Estratégia de Saúde da Família. Trata-se de estudo transversal com amostra de 591 trabalhadores de Equipes de Saúde da Família de João Pessoa-PB, Brasil. Aconselhamento para atividade física foi definido como qualquer recomendação direcionada a aumentar os niveis de atividade fisica dos usuários conduzida por pelo menos seis meses. Foram considerados os seguintes fatores: tempo de trabalho, quantidade de atendimentos, educação permanente, barreiras percebidas, autoeficácia, atitude, autoavaliação de saúde, nível de atividade física e estado nutricional. A prevalência de aconselhamento foi de $46,3 \%$, sendo maior entre médicos (74,5\%; IC95\%: 59,6-85,2) e enfermeiros (60,3\%; IC95\%: 48,0-71,4) em relação aos agentes comunitários de saúde (42,9\%; IC95\%: $38,2-47,7)$ e técnicos de enfermagem (31,5\%; IC95\%: 20,2-45,4). Profissionais com autoavaliação positiva de saúde, sem percepção de barreiras, com atitude positiva e alta autoeficácia, apresentaram maior chance de realizar aconselhamento. Conhecimentos e ações sobre os fatores associados ao aconselhamento podem ajudar a ampliar o envolvimento dos profissionais em iniciativas de educação em saúde.

Palavras-chave Pessoal de saúde, Aconselhamento preventivo, Atenção Primária à Saúde, Atividade motora 


\section{Introduction}

Physical inactivity pandemics are intrinsically related to Non-communicable diseases (NCD) and their death and disease burden ${ }^{1}$. The World Health Organization Global Action Plan for the prevention and control of NCD targeted a $10 \%$ relative reduction in prevalence of insufficient physical activity, and highlighted integrated primary care approaches as a sound strategy for facing NCD burden and to promote physical activity $^{2}$. The Brazilian public health agenda made advances in upscaling physical activity promotion $^{3}$ and primary care has been recognized as a fundamental setting to tackle the burdens related to NCD and promote physical activity ${ }^{4,5}$. Brazil's primary care model is based on the Family Health Strategy which comprehends a robust approach to providing primary care for geographically defined areas based on interprofessional teamwork that includes general practitioners, nurses, nurses assistants, and community health workers ${ }^{6}$. It displays a high population coverage rate $^{7}$ and evidence suggests important population health improvements.

Most interventions in primary care include counseling on physical activity ${ }^{9}$, and it has been advocated as a sound strategy for improving physical activity at the population level ${ }^{10-13}$. There is growing evidence supporting its effectiveness and only few treated patients are needed for observing positive changes in physical activity $(\mathrm{NNT}=12)^{9}$ compared to changing other healthy behavior (e.g. smoking cessation $)^{14}$. However, physical activity counseling is not widely adopted by general practitioners ${ }^{15-18}$ and population based studies have demonstrated that only very few reported patients have been counseled for physical activity ${ }^{19,20}$. Several constraints may hinder adopting counseling practices in primary care in providing routine work as well hampering its quality, such as poor knowledge on physical activity recommendations, lack of time, health providers' personal characteristics, educational opportunities and health service characteristics $^{16,21-23}$.

Given that Brazil has one of the greatest universal healthcare systems in the world and a unique primary health care organization comprised of more than 40 thousand Family Health Teams $s^{24}$, knowledge on physical activity counseling correlates may enlighten avenues for improving health care services and primary health care providers training to conduct health education initiatives. Thus, the aim of this study was to describe physical activity counseling prevalence and associated factors in a sample of Family Health Team workers.

\section{Methods}

This is a cross-sectional study conducted with a representative sample of primary health care workers (General practitioner, nurses, nurse assistant, community health workers) from primary health services of João Pessoa, capital of Paraíba State, Brazil. João Pessoa has approximately 810,000 inhabitants with a mean per capita income of 2.7 minimum wage (approximately USD 690), Gini coefficient for family income of 0.63 , and an infant mortality rate of 13.3 per 1,000 live births.

Primary health care system of João Pessoa is composed by approximately 2,010 workers (192 general practitioners, 204 nurses, 194 nurse assistant and 1,419 community health workers) distributed in 126 family health units across five health districts. Each family health unit is comprised of up to five family health teams according to local territory needs. A sample size of 628 participants was estimated based on a prevalence of physical activity counseling of $50 \%$, a margin error of 5 percentage points, a design effect of 1.5 and an additional sample of $30 \%$ to account for non-response rate. A representative sample of 591 health professionals ( $29.4 \%$ of total population) were recruited based on a random sample of 43 family health units proportionally distributed according to the five local health districts (Districts I to V) and size based on the number of family health teams (single team; $2 / 3$ health teams; 4/5 teams). Proportional distribution of professional categories was guaranteed.

Physical activity counseling was measured by asking the question "Considering physical activity counseling as a structured and general advice for physical activity practice in different domains (i.e. transportation and leisure), mark an option that better represents your behavior related to physical activity counseling". A six option scale based on the transtheoretical model was used as follow: precontemplation (i.e. I do not advise physical activity and I do not intend to begin); contemplation (i.e. I do not counsel physical activity, but I am starting think to do); preparation (i.e. Sometimes I do counsel physical activity, but not in a regular basis); action (i.e. I counsel physical activity, but I started to do it just recently); maintenance (i.e. I have been counseling for 
physical activity for at least 6 months); relapse (i.e. I used to advise physical activity, but I do not do anymore). The maintenance stage was considered to classify health professionals as physical activity counselors ${ }^{21}$.

Work related variables included time working in the Family Health Strategy ( $<5$ vs $\geq 5$ years), number of patients attended per day (excessive [ $3^{\text {rd }}$ tertile $] v s$ non excessive $\left[1^{\text {st }} / 2^{\text {nd }}\right.$ tertiles $]$ ), hours of work (up to 30h/week, 31 to $40 \mathrm{~h} /$ week and $\geq 41 \mathrm{~h} /$ week), and existence of another job besides the Family Health Strategy (yes $v s$ no).

Self-rated health status was measured by asking "How would you rate your health?" and categorized as negative (poor, regular) and positive (good, very good and excellent). Participants also self-reported their weight $(\mathrm{kg})$ and height $(\mathrm{cm})$, and body mass index was used to classify overweight $\left(\geq 25 \mathrm{~kg} / \mathrm{m}^{2}\right)$ and normal weight $(<25 \mathrm{~kg} /$ $\left.\mathrm{m}^{2}\right)^{25}$.

Participants reported duration and frequency of leisure physical activity in the last week based on 19 suggested activities, plus those not listed. Moderate to vigorous physical activity score was computed as a product of frequency (days) by duration ( $\mathrm{min}$ ) of activities reported and participants were classified as physically active $(\geq 150$ $\mathrm{min} /$ week $)$ or inactive $(<150 \mathrm{~min} /$ week $)$ according to current recommendations ${ }^{26}$.

Self-efficacy and attitude were assessed as indicators of psychosocial factors related to physical activity counseling. Self-efficacy was assessed as participants' beliefs about their capabilities to overcome possible difficulties faced for physical activity counseling. Attitude was measured by questions addressing how important physical activity counseling is for health professionals. Perceived barriers for physical activity counseling were measured with a pre-defined list based on previous studies ${ }^{22,27,28}$. The number of items, score range, kappa index, questions and scale characterization are showed on Chart 1 . Scores were summed for psychosocial scales (self-efficacy and attitude) and were dichotomized as low levels ( $1^{\text {st }} / 2^{\text {nd }}$ tertiles $)$ and high levels ( $3^{\text {rd }}$ tertile). Participants who reported at least one barrier were considered exposed (no barrier $v s$ one or more barriers).

Continuing education was assessed using two questions: a) "In the last 12 months, did you participated of any training/extension course of the Municipal Health Department that addressed the topic physical activity and health?"; b) "In the last 12 months, did you received matrix support from the Family Health Support Unit teams on phys- ical activity and health, for example, discussion of clinical cases, continuing education on topics relevant to the teams?”. For both questions a yes/ no option was given.

Lastly, sociodemographic variables included: gender, age (20-39 and $\geq 40$ years old), income (measured as multiple of minimum wage), education (ranging from incomplete elementary education to graduate degree), skin color (white and non-white) and occupation (general practitioners, nurses, assistant nurses and community health workers).

A pilot study was conducted and the questionnaire face validity was assessed by 19 experts in primary health care and physical activity. Also, a reliability study including 54 health professionals showed a mean kappa greater than 0.72 , ranging from 0.45 for psychosocial variables to 0.92 for measuring physical activity counseling practices. Data collection was conducted between May and October 2017 by a trained research team composed of physical education professionals, graduate and undergraduate students. Questionnaires were self-administered on the meeting day of each family health team, and researchers provided help when requested ${ }^{29}$.

We used crude and adjusted logistic regression models for investigating associations. Interaction associations of independent variables and professional categories (graduate vs. undergraduate occupations) were tested, but no significant association was found. For adjusted analysis, we used backward selection and all the independent variables with a $p$-value $<0.20$ were maintained in the model. Adjusted model included age, gender, income and education. The Hosmer-Lemeshow test was used to analyze the quality of the final model. Those associations with a p-value $<$ 0,05 were considered significant.

This study was approved by the Human Research Ethics Committee of the Health Sciences Centre from the Federal University of Paraiba.

\section{Results}

We initially recruited 667 health professionals, of whom 18 refused to participate and 20 were not found after three visits by our team. Then 38 health professionals were excluded because they were on vacation $(n=20)$, sick leave $(n=16)$ or did not answer the majority of questions ( $\mathrm{n}$ $=2$ ). Therefore, our final sample was 591 health professionals, of whom 47 were general practitioners, 69 were nurses, 55 were nurse assistant 
Chart 1. Description of measures of psychosocial factors, perceived barriers to counseling on physical activity and its psychometric properties, João Pessoa (PB), 2017.

\begin{tabular}{|l|r|r|r|l|l|}
\hline $\begin{array}{c}\text { Psychosocial } \\
\text { factors and } \\
\text { barriers }\end{array}$ & $\begin{array}{r}\mathbf{n}^{\circ} \text { of } \\
\text { items }\end{array}$ & Score & Kappa & \multicolumn{1}{c|}{ Questions } & Scale \\
\hline Self-efficacy & 8 & $8-16$ & $\begin{array}{r}0,45(0,18 \\
-0,63)\end{array}$ & $\begin{array}{l}\text { I would be able to conduct physical activity } \\
\text { counseling for users of the Basic Health Unit } \\
\text { even if ... [had no one to teach how to do, I } \\
\text { had lack of knowledge, I did not know places to } \\
\text { practice physical activity, I had no instructional } \\
\text { material... }\end{array}$ & $\begin{array}{l}\text { Dichotomous scale } \\
\text { (yes/no) }\end{array}$ \\
\hline Attitude & 5 & $5-20$ & $\begin{array}{r}0,62(0,53 \\
-0,76)\end{array}$ & $\begin{array}{l}\text { For you, conduct physical activity counseling } \\
\text { for (children/adolescents, adults, elderly, people } \\
\text { with noncommunicable diseases) is.... }\end{array}$ & $\begin{array}{l}\text { 4-point Likert } \\
\text { scale, ranging from } \\
\text { unimportant }=1 \text { to } \\
\text { very important }=4\end{array}$ \\
\hline $\begin{array}{l}\text { Perceived } \\
\text { barriers }\end{array}$ & 8 & - & $0,66(0,62$ \\
$-0,83)$ & $\begin{array}{l}\text { What are the difficulties for you to counsel } \\
\text { users for physical activity? Response options: } \\
\text { lack of time due to work demand; lack } \\
\text { of knowledge about the subject; lack of } \\
\text { professionals to guide how to do counseling; } \\
\text { lack of instructional material; lack of financial } \\
\text { resources of users; I do not perceive any } \\
\text { difficulty; blank space for adding other barriers. }\end{array}$ & $\begin{array}{l}\text { Dichotomous scale } \\
\text { (yes/no) }\end{array}$ & \\
\hline
\end{tabular}

and 419 were community health workers. Most participants $(78.6 \%)$ were female, mean age was 43.2 ( $\mathrm{SD}=9.6$ ) years old, $58.6 \%$ were married, and $72.2 \%$ were non-white. Most participants $(85.1 \%)$ had worked at a Family Health Strategy for at least 5 years, with working hours less than 40 hours/week $(90.5 \%)$ (Table 1$)$.

The prevalence of physical activity counseling was $46.3 \%$ (CI: 42.3-50.3). When analyzing each professional category, general practitioners reported higher levels of physical activity counseling (74.5\%; CI: 59.6-85.2) followed by nurses (60.3\%; CI: 48.0-71.4), community health workers (42.9\%; CI: 38.2-47.7) and nurses assistants (31.5\%; CI: 20.2-45.4) (Figure 1).

Table 2 shows crude and adjusted associations between investigated factors and physical activity counseling. Crude analysis showed that health providers that reported lower daily number of patient consultations, having worked fewer than five years at the Family Health Strategy, being normal weight, having positive self-rated health, perceiving absence of barriers for counseling, and demonstrating higher levels of self-efficacy and attitude were more likely to perform counseling for physical activity. In the multivariate model, health providers that self-rated their health as positive ( $\mathrm{OR}=2.02$; $\mathrm{CI}: 1.33-3.08)$, that demonstrated higher levels of self-efficacy (OR
$=1.79$; CI: $1.18-2.68)$ and attitude $(\mathrm{OR}=1.69$; CI: 1.11-2.45) toward physical activity counseling were more likely to counsel for physical activity. Those health providers that do not report any barrier for counseling were 3 times more likely to counsel for physical activity compared to those who report at least one barrier. The most cited barriers were lack of instructional materials $(37 \%)$, lack of exercise experts for conducting counseling (30\%), poor knowledge about the subject $(24 \%)$ and lack of neighborhood features for physical activity practice (21\%) (data not shown in tables).

\section{Discussion}

The present study aimed to analyze prevalence and associated factors of physical activity counseling among Brazilian primary health care workers. Our results showed over half of health workers do not counsel for physical activity regularly, and prevalence is even lower in low educated professionals (community health workers and nurses' assistants). Health professionals who perceived absence of barriers for counseling, and those who reported higher self-efficacy and attitude for counseling were more likely to practice physical activity counseling. 
Table 1. Sociodemographic and job characteristics of Family Health Strategy workers.

\begin{tabular}{|c|c|c|c|c|c|c|c|c|c|c|}
\hline \multirow{2}{*}{$\begin{array}{c}\text { Characteristic } \\
\text { Variables }\end{array}$} & \multicolumn{2}{|c|}{$\begin{array}{c}\text { General } \\
\text { practitioner }\end{array}$} & \multicolumn{2}{|c|}{ Nurse } & \multicolumn{2}{|c|}{$\begin{array}{c}\text { Nurse } \\
\text { assistant }\end{array}$} & \multicolumn{2}{|c|}{$\mathrm{CHW}^{*}$} & \multicolumn{2}{|c|}{ All } \\
\hline & $\mathbf{n}$ & $\%$ & $\mathbf{n}$ & $\%$ & $\mathbf{n}$ & $\%$ & $\mathbf{n}$ & $\%$ & $\mathbf{n}$ & $\%$ \\
\hline \multicolumn{11}{|l|}{ Gender } \\
\hline Male & 29 & 61.7 & 65 & 97.0 & 53 & 100.00 & 311 & 74.8 & 459 & 78.6 \\
\hline Female & 18 & 38.3 & 2 & 3.0 & - & - & 105 & 25.2 & 125 & 21.4 \\
\hline \multicolumn{11}{|l|}{ Age (year) } \\
\hline $20-29$ & 17 & 37.8 & 3 & 4.5 & 1 & 1.9 & 10 & 2.4 & 31 & 5.3 \\
\hline $30-39$ & 9 & 20.0 & 21 & 31.8 & 18 & 33.3 & 174 & 42.0 & 222 & 38.2 \\
\hline $40-49$ & 2 & 4.4 & 17 & 25.8 & 20 & 37.0 & 140 & 33.7 & 179 & 30.8 \\
\hline$\geq 50$ & 17 & 37.8 & 25 & 37.9 & 15 & 27.8 & 91 & 21.9 & 149 & 25.7 \\
\hline \multicolumn{11}{|l|}{ Schooling } \\
\hline Middle school & - & - & - & - & - & - & 216 & 51.5 & 216 & 36.6 \\
\hline Technician & - & - & - & - & 44 & 80.0 & 76 & 18.1 & 121 & 20.5 \\
\hline Undergraduate & 25 & 53.2 & 16 & 23.2 & 7 & 12.7 & 97 & 23.2 & 145 & 24.5 \\
\hline Graduate degree & 22 & 46.8 & 53 & 76.8 & 4 & 7.3 & 30 & 7.2 & 109 & 18.4 \\
\hline \multicolumn{11}{|c|}{$\begin{array}{l}\text { Income (multiple of minimum wages } \\
\approx 275 \text { US dollars) }\end{array}$} \\
\hline 1 to 2 & - & - & - & - & 55 & 100 & 416 & 100 & 472 & 80.3 \\
\hline 3 to 4 & 6 & 12.8 & 65 & 94.2 & - & - & - & - & 71 & 12.1 \\
\hline$\geq 5$ & 41 & 87.2 & 4 & 5.8 & - & - & - & - & 45 & 7.6 \\
\hline \multicolumn{11}{|c|}{ Time working at FHS $^{\star *}$ (years) } \\
\hline$<5$ & 31 & 65.9 & 13 & 18.8 & 12 & 21.8 & 31 & 7.5 & 87 & 14.9 \\
\hline$\geq 5$ & 16 & 34.4 & 56 & 81.2 & 43 & 78.2 & 381 & 92.5 & 496 & 85.1 \\
\hline \multicolumn{11}{|c|}{ Daily number of patients consultations } \\
\hline 3rd tertile & 14 & 29.8 & 20 & 29 & 18 & 32.7 & 82 & 19.6 & 135 & 22.8 \\
\hline 1st/2nd tertile & 33 & 70.2 & 49 & 71 & 37 & 67.3 & 337 & 80.4 & 456 & 77.2 \\
\hline \multicolumn{11}{|l|}{ Self-rated health } \\
\hline Negative & 45 & 95.7 & 64 & 92.8 & 46 & 85.2 & 378 & 90.4 & 533 & 90.5 \\
\hline Positive & 2 & 4.3 & 5 & 7.2 & 8 & 14.8 & 40 & 9.6 & 56 & 9.5 \\
\hline \multicolumn{11}{|l|}{ Nutritional status } \\
\hline Overweight & 27 & 57.5 & 37 & 55.2 & 38 & 69.1 & 266 & 63.4 & 368 & 62.7 \\
\hline Normal & 20 & 42.5 & 30 & 44.8 & 17 & 30.9 & 152 & 36.4 & 219 & 37.3 \\
\hline \multicolumn{11}{|l|}{ Physical activity level } \\
\hline Inactive & 29 & 61.7 & 24 & 34.8 & 8 & 14.6 & 270 & 64.4 & 210 & 35.6 \\
\hline Active & 18 & 38.3 & 45 & 65.2 & 47 & 85.4 & 149 & 35.6 & 380 & 64.4 \\
\hline \multicolumn{11}{|c|}{$\begin{array}{l}\text { Participation in physical activity } \\
\text { courses }\end{array}$} \\
\hline No & 39 & 84.8 & 55 & 80.8 & 44 & 83.0 & 374 & 91.4 & 512 & 88.9 \\
\hline Yes & 7 & 15.2 & 13 & 19.2 & 9 & 17.0 & 35 & 8.6 & 64 & 11,1 \\
\hline \multicolumn{11}{|c|}{ Support from multiprofessional teams } \\
\hline No & 33 & 70.2 & 35 & 50.7 & 33 & 62.3 & 257 & 62.1 & 358 & 61.4 \\
\hline Yes & 14 & 29.8 & 34 & 49.3 & 20 & 37.7 & 157 & 37.9 & 225 & 38.6 \\
\hline \multicolumn{11}{|c|}{ Perceived barriers for counseling } \\
\hline Yes & 31 & 6.0 & 40 & 58.0 & 41 & 74.5 & 333 & 79.5 & 445 & 75.4 \\
\hline No & 16 & 34.0 & 29 & 29.0 & 14 & 25.5 & 86 & 29.5 & 145 & 24.6 \\
\hline \multicolumn{11}{|l|}{ Self-efficacy for counseling } \\
\hline Lower & 29 & 65.9 & 39 & 58.2 & 38 & 73.1 & 306 & 79.1 & 378 & 68.9 \\
\hline Higher & 16 & 34.1 & 28 & 41.8 & 14 & 26.9 & 81 & 20.9 & 171 & 31.1 \\
\hline Attitude for counseling & & & & & & & & & & \\
\hline Lower & 31 & 66.0 & 38 & 56.7 & 38 & 74.5 & 327 & 79.2 & 322 & 57.4 \\
\hline Higher & 16 & 34.0 & 29 & 43.3 & 13 & 24.5 & 86 & 20.2 & 246 & 42.6 \\
\hline
\end{tabular}

${ }^{\star}$ CHW: Community Health Worker; ${ }^{* *}$ FHS: Family Health Strategy. 
Table 2. Crude and adjusted analysis of association between investigated factors and physical activity counseling among Family Health Strategy workers.

\begin{tabular}{|c|c|c|c|c|c|}
\hline \multirow{3}{*}{ Characteristic } & \multicolumn{5}{|c|}{ Physical activity counseling } \\
\hline & \multirow{2}{*}{$\%$} & \multicolumn{2}{|c|}{ Crude } & \multicolumn{2}{|c|}{ Adjusted $^{*}$} \\
\hline & & OR & 95\%CI & OR & 95\%CI \\
\hline \multicolumn{6}{|l|}{ Time working at FHS (years) } \\
\hline$\geq 5$ & 44.3 & 1 & & 1 & \\
\hline$<5$ & 58.6 & 1.78 & $(1.12-2.82)$ & 1.21 & $(0.67-2.18)$ \\
\hline \multicolumn{6}{|c|}{ Daily number of patients consultations } \\
\hline 3rd tertile & 38.0 & 1 & & 1 & \\
\hline 1st/2nd tertile & 48.8 & 1.55 & $(1.04-2.29)$ & 1.44 & $(0.91-2.27)$ \\
\hline \multicolumn{6}{|l|}{ Self-rated health } \\
\hline Negative & 33.5 & 1 & & 1 & \\
\hline Positive & 53.1 & 2.24 & $(1.57-3.20)$ & 2.02 & $(1.33-3.08)$ \\
\hline \multicolumn{6}{|l|}{ Nutritional status } \\
\hline Overweight & 42.9 & 1 & & 1 & \\
\hline Normal & 52.1 & 1.44 & $(1.03-2.02)$ & 0.85 & $(0.57-1.27)$ \\
\hline \multicolumn{6}{|l|}{ Physical activity level } \\
\hline Inactive & 41.2 & 1 & & 1 & \\
\hline Active & 55.5 & 1.77 & $(1.26-2.49)$ & 0.72 & $(0.48-1.08)$ \\
\hline \multicolumn{6}{|c|}{ Participation in physical activity courses } \\
\hline No & 46.2 & 1 & & - & \\
\hline Yes & 49.2 & 1.12 & $(0.65-1.27)$ & - & - \\
\hline \multicolumn{6}{|c|}{ Support from multiprofessional teams } \\
\hline No & 47.6 & 1 & & - & \\
\hline Yes & 45.3 & 0.91 & $(0.65-1.27)$ & - & - \\
\hline \multicolumn{6}{|l|}{ Perceived barriers for counseling } \\
\hline Yes & 38.8 & 1 & & & \\
\hline No & 69.4 & 3.65 & $(2.42-5.51)$ & 3.49 & $(2.17-5.62)$ \\
\hline \multicolumn{6}{|l|}{ Self-efficacy for counseling } \\
\hline Lower & 41.1 & 1 & & 1 & \\
\hline Higher & 57.8 & 1.96 & $(1.36-2.84)$ & 1.79 & $(1.18-2.68)$ \\
\hline \multicolumn{6}{|l|}{ Attitude for counseling } \\
\hline Lower & 38.7 & 1 & 1 & 1 & 1 \\
\hline Higher & 58.3 & 2.21 & $(1.57-3.09)$ & 1.69 & $(1.11-2.45)$ \\
\hline
\end{tabular}

$\mathrm{OR}=$ odds ratio; $95 \% \mathrm{CI}=95 \%$ confidence interval. ${ }^{\star}$ Adjusted for all variables plus time working at FHS, number of daily patients consultations, self-rated health, nutritional status, physical activity level, perceived barriers for counseling, Self-efficacy for counseling, Attitude for counseling, age, gender and schooling.

Ideally, all primary health care workers would be able to counseling for physical activity and other health behaviors, as one of primary care services targets is health education and health promotion. However, less than half of the health professionals reported counseling regularly. Physicians' physical activity counseling prevalence founded herein was similar to findings in other countries with universal health systems, such as Germany $(55 \%)^{30}$ and Canada $(70 \%)^{18}$ and also corroborates previous studies with Brazilian nurses and general practitioners $(69 \%)^{15}$. In fact, physicians are more frequently cited as counselors by Brazilian patients ${ }^{19}$. We hypothesized that patients seek physicians' services more as they are considered trusted sources of health information by patient $s^{31}$. Also, general practice consultations are among the most frequent services offered in family health units ${ }^{32}$, so they have more opportunities for health education interventions such as counseling. Moreover, the fact that health education interventions of general practitioners represent an alternative approach to drug prescriptions, therefore a positive fact being that 


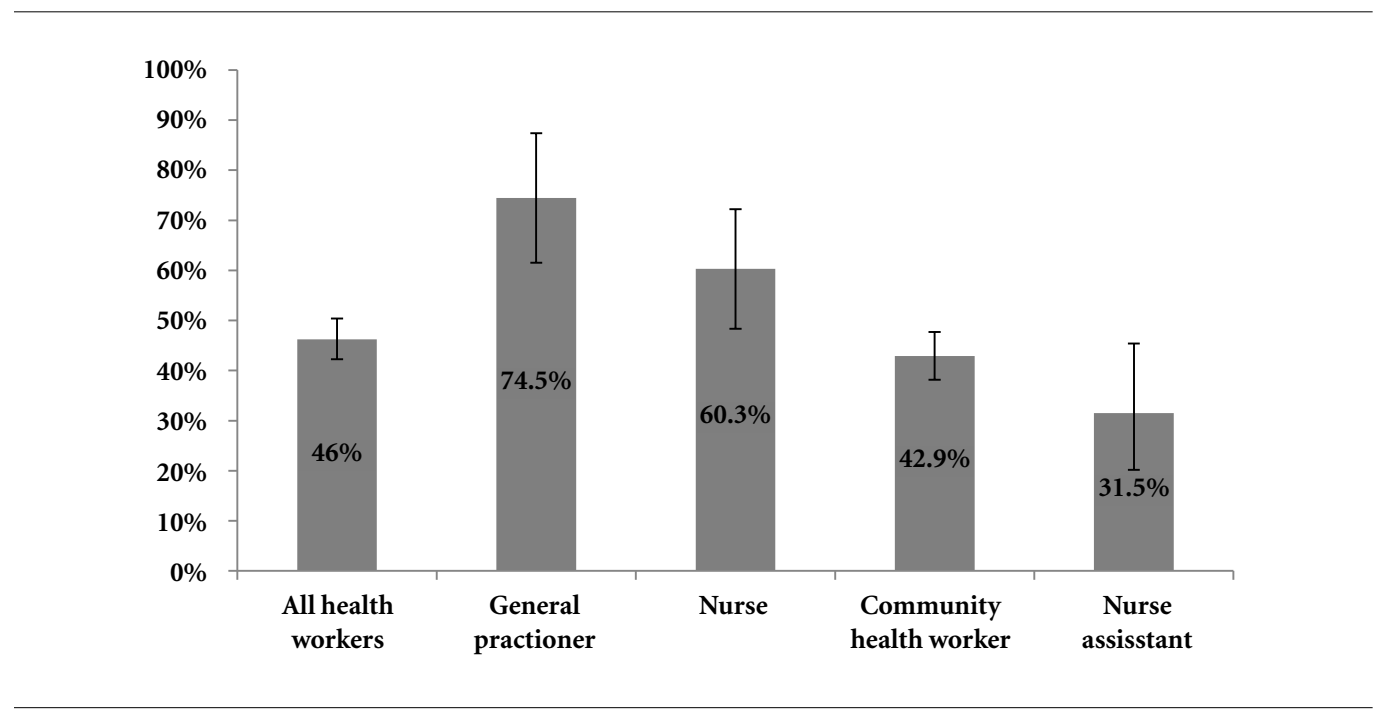

Figure 1. Prevalence of physical activity counseling according to different health care workers.

Brazilian Primary Care Policy ${ }^{33}$ states that health education initiatives are an attribution of all primary health care workers included in the team.

Undergraduate educational background may facilitate physical activity counseling among general practitioners compared to nurses and low educated health care providers. Although we have no data about Brazilian medical schools and physical activity content in its curricula, we believe that physicians have a broader training that surrounds this subject. Despite this, both Brazilian general practitioners and nurses self-rated their knowledge as insufficient and incorrectly responded to physical activity recommendations $s^{15}$. A lack of knowledge on how to conduct physical activity counseling seems to be a common obstacle that hinders efforts in physical activity promotion in primary health care services ${ }^{13,22}$, probably as a result of poor curriculum in medical school $^{34,35}$. In contrast, changes in curricula of medical and other health schools are not appropriately addressed, and an opportune way for improving physical activity counseling is by means of in-service training of all primary care workers, which is in consonance with the National Permanent Health Education Policy ${ }^{36}$. In Brazil, NASF can contribute to meet this goal, as its attribution is to support primary care teams with health assistance and technical and pedagogical background. The NASF brings together various health care providers to coordinate the highest possible quality of care for patients assisted by family health teams ${ }^{37}$. It may consist of social workers, physical education teachers, pharmacists, physiotherapists, speech therapists, nutritionists, psychologists, or other health professionals who collaboratively work in order to improve the autonomy of the family health team. Thus, it would be reasonable that physical education teachers provide support for general practitioners, nurses, and community health workers to promote physical activity in their routine work. Nevertheless, our data suggest more attention is needed to continuing education of the family health team. We found no association between continuing education provided both by NASF team or municipal health office and physical activity counseling among family health workers. Also, self-efficacy and attitude for physical activity were associated with counseling, and therefore these are factors which can be shaped by educational interventions aimed to improve competence for physical activity counseling among primary care workers, covering knowledge, skills and attitude contents.

Another direction for improving health promotion practices among primary care providers is betting on their own health status. Convincing evidence shows the health of primary care workers matters and health provider workers' own physical activity levels, nutritional status and eating habits influence their clinical attitudes towards physical activity ${ }^{38,39}$. Due to poor statistical 
power we did not find any statistical significance on the association between physical activity with counseling practices. However, if we take into account self-rated health as an indicator of overall health status ${ }^{40}$, our data endorse the idea that investing in workers' health is not only imperative to improve their own health, but also their behavioral counseling practices addressed to community. Additionally, it seems that primary care workers claim interventions targeting their own health, mainly through self-care and physical activity practices ${ }^{41,42}$. When looking at the big picture of Brazilian primary health care workers, it seems that work conditions (e.g., work overload, stress) have an important role in job satisfaction and self-rated health ${ }^{43}$.

Although personal characteristics of health providers play an important role in their competence to conduct health behavior counseling, contextual factors have its place either hindering or facilitating work capabilities in health work. Lack of time, lack of knowledge/training, lack of financial incentive, lack of counseling protocols and organizational barriers are examples of obstacles reported by physicians and nurses to not counsel for physical activity ${ }^{22}$. Our study covered two factors that could play a role in physical activity counseling practices. First, we hypothesized that health providers with more time working at the Family Health Strategy would be less compromised by its rules and working process compared to newer workers as they could have experienced the health care model in a primary health organization prior to the actual model - traditional model. The traditional health care model is biomedical oriented and disease centered, so health behavior education would not be prioritized ${ }^{44}$. Our data pointed to this assumption in the crude analysis, but adjustment for health workers' age partially explained associations between less time at the Family Health Strategy and higher rates of physical activity counseling. Second, we used the number of patients consulted on a daily basis as a proxy of workload that could be related to health behavior counseling practices. Possibly because using an arbitrary measure (upper $v s$. mid/lower tertile) of number of consultations, we were unable to demonstrate its association with counseling practices. Lack of time is a major barrier cited by physicians and nurses with respect to physical activity counseling ${ }^{22,45}$ and number of patients attended is closely related to this perception ${ }^{15}$. Recommendations to overcome time constraints include using waiting room as an opportunity to conduct a physical activity assessment or even health education initiatives, the use of structured models of health counseling (i.e. 5 A's model), use of written materials, and so on. Alongside these alternatives, rethinking organizational features of primary health care in order to advance for a more balanced delivery of promotional, preventive, curative, rehabilitative, and supportive/palliative care is needed.

Although time constraints is a major obstacle, it is not the only one ${ }^{22}$. In fact, when asked about perception of barriers, primary health workers cited a lack of instructional materials, lack of exercise experts for teaching how to conduct physical activity counseling, poor knowledge about the subject and lack of neighborhood features for physical activity practice as major barriers. We found health workers who did not perceive any obstacle for physical activity counseling were three times more likely to counsel for physical activity than their peers who perceived some barrier. Although these barriers are mainly a result of contextual factors, which claims for broader changes in the work setting, we also believe that high self-efficacy level and a positive attitude plays an important role to attenuate or even overcome health worker's understanding that these are impeditive constraints. In fact, our results showed health workers with higher self-efficacy level and a positive attitude towards physical activity were more likely to counsel for physical activity. As abovementioned, we believe in-service training alongside physical activity promotion of health workers comprises the main approach for improving general competence for physical activity counseling on a regular basis. Experiences in continuing education for community health workers ${ }^{42}$, medicine residents ${ }^{46}$ and even e-learning ${ }^{47}$ approaches have been tested and demonstrated promising results.

This study has two main limitations which should be considered when interpreting these findings. First, our measure of physical activity counseling did not cover what it really consists of and how it is delivered. So, although we generically defined what physical activity counseling is on the question statement, health workers may have a divergent understanding on it. Second, social desirability may have an impact on the prevalence levels found herein, and we are not certain about how it may differ across different professional categories. Direct observation has been used in order to overcome these limitations ${ }^{47}$, but it may impact on the findings as a result of reactiveness to being observed. Also, it would not be feasible for an epidemiologic study. On the oth- 
er hand, an adequate sample size, use of a tested questionnaire and a high response rate all contribute to internal and external validity.

We conclude that both personal and health service characteristics may hamper physical activity counseling among primary health care providers. Future studies should more deeply explore how initial education, in-service training and work process organization could help improve levels of counseling by overcoming barriers related to knowledge, skills and attitudes about physical activity counseling.

\section{Referências}

1. World Health Organization (WHO). Global status report on noncommunicable diseases 2014. Geneva: WHO; 2014.

2. World Health Organization (WHO). Global strategy on diet and physical activity. World Health Assembly. Geneva: WHO; 2004.

3. Malta DC, Barbosa JS. Policies to promote physical activity in Brazil. Lancet 2012; 380(9838):195-196.

4. Brasil. Ministério da Saúde (MS). Secretaria de Vigiância em Saúde. Secretaria de Atenção à Saúde. Política nacional de promoção da saúde (PNPS): revisão da Portaria MS/GM $n^{\circ}$ 687, de 30 de março de 2006. Brasília: MS; 2015.

5. Brasil. Ministério da Saúde (MS). Secretaria de Vigilância em Saúde. Departamento de Análise de Situação de Saúde. Plano de ações estratégicas para o enfrentamento das doenças crônicas não transmissiveis (DCNT) no Brasil 2011-2022. Brasília: MS; 2011.

6. Macinko J, Harris MJ. Brazil's Family Health Strategy - Delivering Community-Based Primary Care in a Universal Health System. N Engl J Med 2015; 37(2):2177-2181.

7. Malta DC, Santos MAS, Stopa SR, Vieira JEB, Melo EA, Reis AAC. Family Health Strategy coverage in Brazil, according to the National Health Survey, 2013. Cien Saude Colet 2016; 21(2):327-338.

8. Bastos ML, Menzies D, Hone T, Dehghani K, Trajman A. The impact of the Brazilian family health on selected primary care sensitive conditions: A systematic review. PLoS One 2017; 12(8):e0182336.

9. Orrow G, Kinmonth A, Sanderson S, Sutton S. Effectiveness of physical activity promotion based in primary care : systematic review and meta-analysis of randomised controlled trials. BMJ 2012; 344:e1389.

10. National Institute for Health and Care Excellence (NICE). Physical activity: brief advice for adults in primary care. NICE; 2013.

\section{Collaborations}

JM Souza Neto worked on the design, development of the study and writing of the manuscript. AA Florindo participated in the conception and final revision of the manuscript. FF Costa worked on designing, developing the study and writing the manuscript.

\section{Acknowledgements}

The authors wish to thank all those people who directly or indirectly contributed to this project, especially professionals, managers and funding agency (CAPES scholarship).

11. LeFevre ML. Behavioral counseling to promote a healthful diet and physical activity for cardiovascular disease prevention in adults with cardiovascular risk factors: U.S. Preventive Services Task Force Recommendation Statement. Ann Intern Med 2014; 161(8):587-593.

12. Reis RS, Salvo D, Ogilvie D, Lambert E V, Goenka S, Brownson RC. 2016. Scaling up physical activity interventions worldwide: stepping up to larger and smarter approaches to get people moving. Lancet 2016; 388(10051):1337-1348.

13. Vuori IM, Lavie CJ, Blair SN. Physical activity promotion in the health care system. Mayo Clin Proc 2013; 88(12):1446-1461.

14. Van Schayck OCP, Williams S, Barchilon V, Baxter N, Jawad M, Katsaounou PA, Kirenga BJ, Panaitescu C, Tsiligianni IG, Zwar N, Ostrem A. 2017. Treating tobacco dependence: guidance for primary care on life-saving interventions. NPJ Prim Care Respir Med 2017; 27(1):38.

15. Florindo AA, Mielke GI, Gomes GADO, Ramos LR, Bracco MM, Parra DC, Simoes EJ, Lobelo F, Hallal PC. Physical activity counseling in primary health care in Brazil: a national study on prevalence and associated factors. BMC Public Health 2013; 13:794.

16. Ma J, Urizar GG, Alehegn T, Stafford RS. Diet and physical activity counseling during ambulatory care visits in the United States. Prev Med 2004; 39(4):815822.

17. Omura JD, Bellissimo MP, Watson KB, Loustalot F, Fulton JE, Carlson SA. Primary care providers' physical activity counseling and referral practices and barriers for cardiovascular disease prevention. Prev Med 2018; 108:115-122.

18. Petrella RJ, Lattanzio CN, Overend TJ. Physical Activity Counseling and Prescription Among Canadian Primary Care Physicians. Arch Intern Med 2007; 167(16):1774-1781. 
19. Duro SMS, Tomasi E, Siqueira F, Silveira DS, Thume E, Facchini L. Adult physical activity counseling by health professionals in Brazil: a national urban population survey. J Phys Act Health 2015; 12(8):11771183.

20. Siqueira FV, Nahas MV, Facchini LA, Silveira DS, Piccini RX, Tomasi E, Thumé E, Hallal PC. Counseling for physical activity as a health education strategy. Cad Saude Publica 2009; 25(1):203-213.

21. Florindo AA, Mielke GI, Gomes GAO, Ramos LR, Bracco MM, Parra DC, Simoes EJ, Lobelo F, Hallal PC. Physical activity counseling in primary health care in Brazil: a national study on prevalence and associated factors. BMC Public Health 2013; 13:794.

22. Hebert ET, Caughy MO, Shuval K,. Primary care providers' perceptions of physical activity counselling in a clinical setting: a systematic review. Br J Sports Med 2012; 46(9):625-631.

23. Huijg JM, Gebhardt WA, Verheijden MW, Van der Zouwe N, Vries J.D, Middelkoop BJC, Crone M.R. Factors influencing primary health care professionals' physical activity promotion behaviors: a systematic review. Int J Behav Med 2014; 22(1):32-50.

24. Aly CMC, Reis AT, Carneiro SAM, Moraes LFS. O Sistema Único de Saúde em série histórica de indicadores: uma perspectiva nacional para ação. Saúde Debate 2017; 41(113):500-512.

25. World Health Organization (WHO). Global recommendations on physical activity for health. Geneva: WHO; 2010.

26. World Health Organization (WHO). Global recommendations on physical activity for health. Geneva: WHO; 2010

27. Burdick L, Mielke GI, Parra DC, Gomes G, Florindo A, Bracco M, Lobelo F, Simoes EJ, Pratt M, Ramos LR, Moura L, Brownson RC, Hallal PC. Physicians', nurses' and community health workers' knowledge about physical activity in Brazil: A cross-sectional study. Prev Med Rep 2015; 2:467-472.

28. Virgílio M, Barros G, Lemos EC, Silva, JRA, Silva CRM, Tassitano RM. Evaluation of programs and interventions for physical activity promotion in primary health care in Pernambuco : construction and validation of instruments and fieldwork methods of the SUS + Ativo Project. Rev Bras Ativ Fis Saude 2016; 21(5):388-399.

29. Souza Neto JM. Prevalência e fatores associados à prática do aconselhamento para a atividade física em profissionais de saúde [dissertação]. João Pessoa: Universidade Federal da Paraíba; 2018.

30. Bock C, Diehm C, Schneider S. Physical activity promotion in primary health care: results from a German physician survey. Eur J Gen Pr 2012; 18(2):86-89.

31. Vuori IM, Lavie CJ, Blair SN, Physical activity promotion in the health care system. Mayo Clin Proc 2013; 88(12):1446-1461

32. Tomasi E, Facchini LA, Thumé E, Piccini RX, Osorio A, Silveira DS, Siqueira FV, Teixeira VA, Dilélio AS, Maia MFS. Characteristics of primary healthcare service use in the southern and northeastern regions of Brazil: differences by care model. Cien Saude Colet 2011; 16(11):4395-4404.

33. Brasil. Ministério da Saúde (MS). Secretaria de Atenção à Saúde. Departamento de Atenção Básica. Política Nacional de Atenção Básica. Brasília: MS; 2012.
34. Garry JP, Diamond JJ, Whitley TW. Physical activity curricula in medical schools. Acad Med 2002; 77(8):818-820.

35. Weiler R, Chew S, Coombs N, Hamer M, Stamatakis E. Physical activity education in the undergraduate curricula of all UK medical schools: are tomorrow's doctors equipped to follow clinical guidelines? $\mathrm{Br} \mathrm{J}$ Sport Med 2012; 46(14):1024-1026.

36. Brasil. Ministério da Saúde (MS). Secretaria de Gestão do Trabalho e da Educação na Saúde. Política Nacional de Educação Permanente em Saúde. Brasília: MS; 2009.

37. Brasil. Ministério da Saúde (MS). Secretaria de Atenção à Saúde. Departamento de Atenção Básica. Diretrizes do NASF: Núcleo de Apoio a Saúde da Família. Brasília: MS; 2010.

38. Frank E, Segura C, Shen H, Oberg E. Predictors of Canadian physicians' prevention counseling practices. Can J Public Heal 2010; 101(5):390-395.

39. Lobelo F, Quevedo IG. The evidence in support of physicians and health care providers as physical activity role models. Am J Lifestyle Med 2014; 10(1):36-52.

40. Wu S, Wang R, Zhao Y, Ma X, Wu M, Yan X, He J, The relationship between self-rated health and objective health status: a population-based study. BMC Public Health 2013; 13:320.

41. Florindo AA, Andrade DR, Guerra PH, Mota J, Crone D, Mafra ACCN, Bracco MM. Physical activity promotion by health practitioners: a distance-learning training component to improve knowledge and counseling. Prim Heal Care Res Dev 2017; 19(2):140-150.

42. Florindo AA, Costa EF, Sa TH, Ishii T, Velardi M, Andrade DR. Physical activity promotion in primary health care in Brazil: a counseling model applied to community health workers. J Phys Act Heal 2014; 11(8):1531-1539.

43. Garcia LP, Hofelmann DA, Facchini LA. Auto-avaliação de saúde e condições de trabalho entre trabalhadores de centros de atenção primária à saúde no Brasil. Cad Saude Publica 2010; 26(5):971-980.

44. Fertonani HP, Pires DEP, Biff D, Scherer MDA. The health care model: concepts and challenges for primary health care in Brazil. Cien Saude Colet 2012; 20(6):1869-1878.

45. Eakin EG, Smith BJ, Bauman AE. Evaluating the Population Health Impact of Physical Activity Interventions in Primary Care -Are We Asking the Right Questions? J Phys Act Heal 2005; 2:197-215.

46. Hill LL, Nichols J, Wing D, Waalen J, Friedman E. Training on Exercise is Medicine ${ }^{\circledR}$ Within an Integrative Medicine Curriculum. Am J Prev Med 2015; 49(5 Supl. 3):S278-S284

47. Florindo AA, Andrade DR, Guerra PH, Mota J, Crone D, Mafra ACCN, Bracco MM. Physical activity promotion by health practitioners: A distance-learning training component to improve knowledge and counseling. Prim Heal Care Res 2018; 19(2):140-150.

Article submitted 18/10/2018

Approved 19/04/2019

Final version submitted 21/04/2019

Chief Editors: Romeu Gomes, Antônio Augusto Moura da Silva 